\title{
Analysis of Manually Cable Pulling Process in Construction Site on the Pipe Rack with REBA (Rapid Entire Body Assessment)
}

\section{Hakan ERDOGAN}

Institute Business Management and Law, Russia

\section{Oguz OZYARAL}

Istanbul Rumeli University, Turkey

\section{Esra ERDOGAN}

University of Health Sciences, Ankara - Turkey

(C) The Author(s) 2018

\begin{abstract}
Productivity and product quality depend on employee performance. Postures, working environment and method of statement affect the employee performance. Deficiencies in the work environment and the lack of proper postures cause a decrease in employee performance and musculoskeletal disorders. Improper working postures cause to the development of musculoskeletal disorders. Ergonomic analysis is done to evaluate improper postures in order to avoid the formation and becoming permanent of these disorders. According to health records, employees who were working at cable pulling had musculoskeletal disorders such as backache, hand and elbow pains. They have taken bill of health and not come work. Therefore, additionally healthy problems employees there were lost time and unavoidable delays in process. Rapid Entire Body Assessment (REBA) is one of the ergonomic analysis methods. It does not require advanced knowledge and experience in ergonomics. In this study, due to increment healthy problems and days of temporary incapacity who work at manually cable pulling process in construction site on the pipe rack, forces on hand are measured with a mechanical force gauges and all data are evaluated with REBA. Cable pulling process is analyzed and precautions are defined.
\end{abstract}

(C)2018.All rights reserved

\section{ARTICLE HISTORY}

Received: $17 / 04 / 2018$

Accepted: 02/08/2018

Published online: 05/10/2018

\section{KEYWORDS}

Cable pulling, Ergonomic analysis, REBA (Rapid Entire Body Assessment) 


\section{Introduction}

Each tissue such as muscle, cartilage and bone goes through many different mechanisms of differentiation. Bones, muscles, ligaments, tendons and cartilage are affected from Musculoskeletal Disorders (MSDs). Epidemiological studies have found a binding between MSDs and handling, lifting, vibration, incompatible postures ( Kirkhorn , Earle-Richardson \&Banks,2010) . MSDs causes disablement, rise on costs, further delay works, lost working days (Levy, Wegman,2000) . Healthy problems such as tissue injuries, pains etc. affect the daily life quality of the employee (3). MSDs are prevalently related with manual materials handling (Marras, 2000). Repetitive manual materials handling such as cable pulling process may lead to tissue injuries, contusion, tendinitis, carpal tunnel syndrome, fatigue, sprains and strains, pains (Das\& Gangopadhyay ,2005). MSDs conduce to a grave problem because of economic losses, decreasing in productivity, many absences. Therefore, risk evaluation is important to reduce hazards and taking precautions (7). REBA has a low application cost and useful to determine different ergonomic hazards and several biomechanical risk factors. Also it does not require advanced knowledge and experience in ergonomics. The REBA was found out in 2000 with investigation 600 postural examples with objective of evaluation risky postures in the development of MSDs (8-13). REBA includes systematic process to obtain whole body postural MSDs and hazards related to job tasks. There are several studies on REBA risk assessment (9-11), but there has been no study recorded on cable pulling process is found. So that the aim of this study is to investigate for reducing ailments and economic losses on manually cable pulling process at construction sites with using Rapid Entire Body Assessment (REBA) ergonomic analysis method results.

\section{Method}

The risks of a working posture or movement is expressed numerically by using REBA risk assessment method. Cable pulling process is analyzed varying in loads and postures based on the diagrams of the body part (Group A and B) from Figure 1. Trunk, neck, legs, shoulders, elbows, wrists, coupling, load and activity are considered and REBA score is obtained between 1 and 15 . When REBA score is calculated, working postures are divided into A and B groups. Trunk, neck and legs are considered for A group scores. Upper arms, elbows, wrists are considered B groups scores. After load (force) and coupling adding, score C is found. Activity score added $\mathrm{C}$ score and final REBA score is obtained. REBA Precautions Levels is decided according to this final REBA score (McAtamney, Corlett, 1993). 


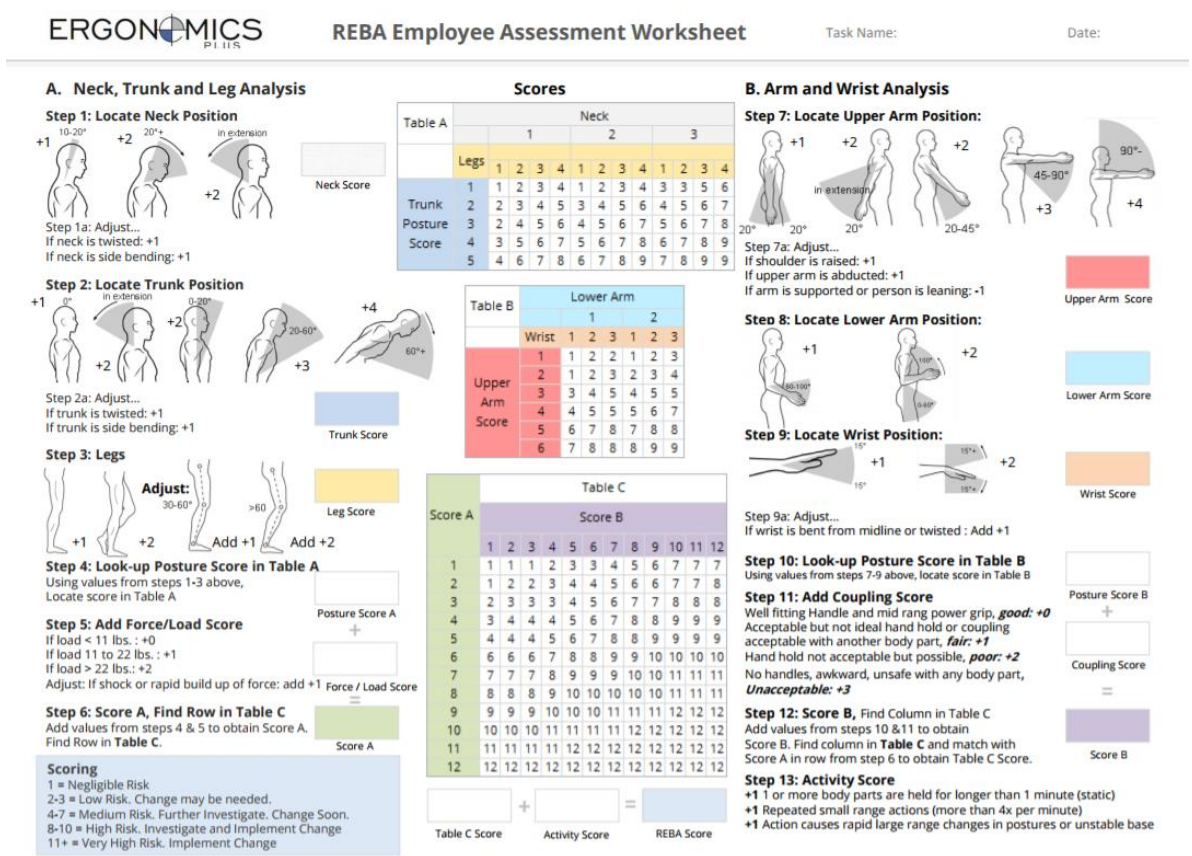

Figure 1: REBA Employee Assessment Worksheet

Ergonomists and other implementers use commonly REBA. This method necessitates a little knowledge, training and practice. Application of method are not required ergonomic skills (15-18). This study carried out with 135 employees in Volgograd Deep Conversion Project (Refinery construction project that is built by Tecnicas Reunidas S.A). On Figure1 REBA Employee Assessment Worksheet has seen.

\section{Results}

There are totally 30 employees at 18-25 ages, 48 employees at 26-35 ages and 57 employees at over 36 ages. When we have get healthy records about cable pulling employees, we obtained table 1 data after job specification-description. It is observed that total number of employees who have healthy records are 21 mild low-back pain, 12 severe low back pain, 14 mild low hand and leg pain, 9 Severe low hand and leg pain and 17 soft tissue injury. 18 and 25 ages employees have 5 mild low-back pain, 1 severe low back pain, 2 mild low hand and leg pain, 1 severe low hand and leg pain and 5 soft tissue injury. 26 and 35 ages employees have 11 mild low-back pain, 4 severe low back pain, 5 mild low hand and leg pain, 2 Severe low hand and leg pain and 5 soft tissue injury. Over 35 age's employees 
have 5 mild low-back pain, 7 severe low back pain, 7 mild low hand and leg pain, 6 Severe low hand and leg pain and 7 soft tissue injury. Also days of temporary incapacity is 448. Healthy records that is about only cable pulling employees in 6 months seen on Table 1 .

Table 1: Healthy records that is about only cable pulling employees in 6 months.

\begin{tabular}{|l|l|l|l|l|l|}
\hline Ailments & $\begin{array}{l}\text { Number of } \\
\text { employees }\end{array}$ & $\begin{array}{l}18-25 \text { ages } \\
\text { employees }\end{array}$ & $\begin{array}{l}\text { 26-35 ages } \\
\text { employees }\end{array}$ & $\begin{array}{l}\text { Over 35 } \\
\text { ages } \\
\text { employees }\end{array}$ & $\begin{array}{l}\text { Days of } \\
\text { temporary } \\
\text { incapacity }\end{array}$ \\
\hline $\begin{array}{l}\text { mild low-back } \\
\text { pain }\end{array}$ & 21 & 5 & 11 & 5 & 58 \\
\hline $\begin{array}{l}\text { severe low back } \\
\text { pain }\end{array}$ & 12 & 1 & 4 & 7 & 168 \\
\hline $\begin{array}{l}\text { Mild low hand } \\
\text { and leg pain }\end{array}$ & 14 & 2 & 5 & 7 & 34 \\
\hline $\begin{array}{l}\text { Severe low } \\
\text { hand and leg } \\
\text { pain }\end{array}$ & 9 & 1 & 2 & 6 & 120 \\
\hline $\begin{array}{l}\text { soft tissue } \\
\text { injury }\end{array}$ & 17 & 5 & 5 & 7 & 67 \\
\hline Total & 73 & 14 & 27 & 32 & 448 lost day \\
\hline
\end{tabular}

According to this healthy reports we analysis cable pulling process and posture on tray. (Figure 2) At pipe rack we use Mechanical Force Gauges (Figure 3 ) to measurement of pulling cable on the electricity tray. For each age's groups we obtained average applied forces. The force data are changed according to pulling distance. It is between $8-10 \mathrm{~kg}$.

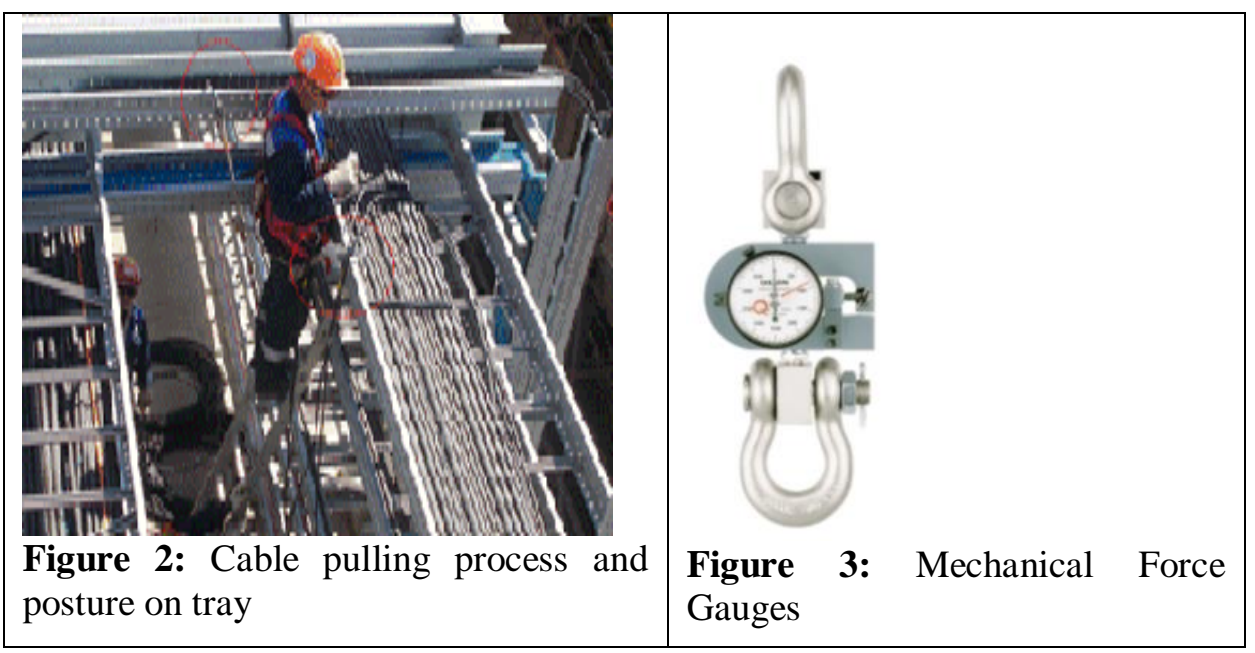

Int.J. Hum. Soc. Dev. Res.

Volume 2, № 2, 2018.66-78 
Group A tables (Trunk, neck and legs data's recorded on Table 2).

$\checkmark$ Trunk score is obtained using both flexion $20-60^{\circ}$ \& extension more than $20^{\circ}$ and side flexed. Score is $3+1$

$\checkmark$ Neck score is obtained using both Flexion $>20^{\circ}$ \& Extension $>20^{\circ}$ and side flexed. Score is $3+1$

$\checkmark$ Legs score is obtained using both Unstable and Knee(s) Flexion 30-60 . Score is $2+1$

Table 2: Group A scores (Trunk, neck, legs)

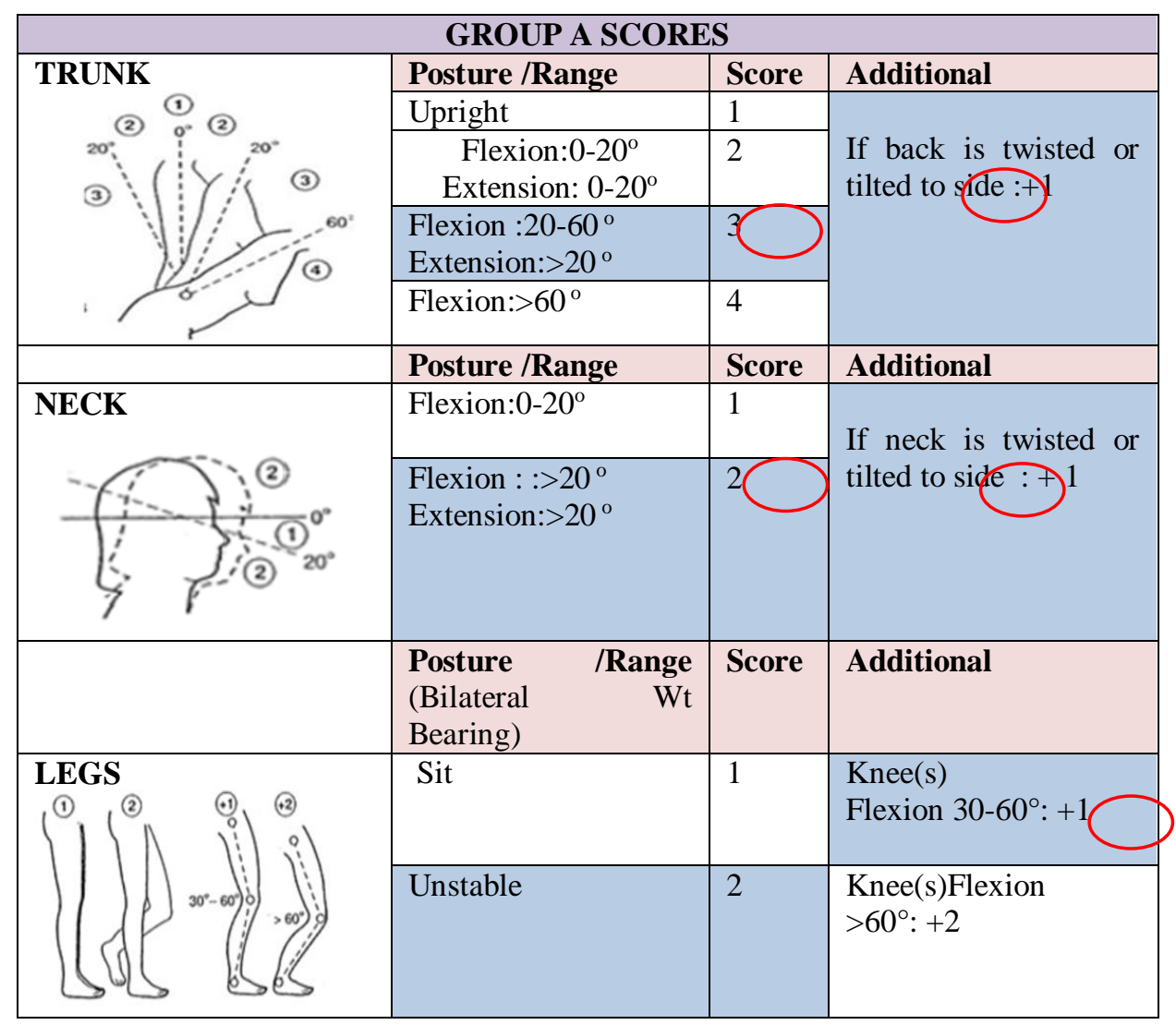

Group B tables (shoulders, elbows and wrists data's recorded on Table 3).

$\checkmark$ Upper arms score is obtained using both Flexion: 20-45 \& Extension: :> $20^{\circ}$ and arm abducted /rotated score. And also added arm supported score. Score is 2+1-1 
$\checkmark$ Lower arms score is obtained using Flexion: $\left\langle 60^{\circ}\right.$ and Flexion :> $100^{\circ}$ .Score is 2

$\checkmark$ Wrists score is obtained using both Flexion: $>15^{\circ} \&$ Extension: $>15^{\circ}$ and Wrist deviated/twisted score. Score is $2+1$.

Using other scores tables (the data's of Load, Coupling and activity scores are shown at Table 4)

$\checkmark$ Load/Force score equals $1+1$

$\checkmark$ Coupling is good for this process. Score is 0 .

$\checkmark$ We need activity score for final Reba score. The score is +1 .

We find out Score A with using Table A. Neck, Legs and Trunk scores are intersected. Score A is 7, recorded in Table 5. We find out Score B with using Table B. Lower arm, wrist and upper arm are intersected. Score B is 4 seen at Table 5.

Score C is obtained using both Score-A and Score-B. Score is 9 founded on Table 6.

Total score is calculated 10 seen on Figure 4, this refers to a REBA action level of 3 recorded on Table 7 .

Table 3: Group B scores ( shoulders ,elbows and wrists )

\begin{tabular}{|c|c|c|c|}
\hline \multicolumn{4}{|l|}{ GROUP B SCORES } \\
\hline \multirow{2}{*}{$\begin{array}{ll}\text { UPPER } & \text { ARMS } \\
\text { (SHOULDERS) }\end{array}$} & Posture /Range & Score & Left and Right \\
\hline & $\begin{array}{l}\text { Flexion:0-20 } \\
\text { Extension } 0-20^{\circ}\end{array}$ & 1 & \multirow{4}{*}{$\begin{array}{l}\text { Arm Abducted } \\
\text { /Rotated } \\
\text { :-1 } \\
\text { Shoulder Raised: }+1\end{array}$} \\
\hline \multirow{5}{*}{ (2) $($ (1) (1) (2) } & Flexion: $20-45^{\circ}$ & 2 & \\
\hline & Extension: : $>20^{\circ}$ & & \\
\hline & Flexion: $45-90$ & 3 & \\
\hline & & & \multirow[t]{2}{*}{ Arm Supported : -1} \\
\hline & Flexion : $>90^{\circ}$ & 4 & \\
\hline & Posture /Range & Score & Left and Right \\
\hline \multirow{3}{*}{$\begin{array}{ll}\text { LOWER } & \text { ARMS } \\
\text { (ELBOWS) }\end{array}$} & Flexion: $60-100^{\circ}$ & 1 & \multirow[b]{2}{*}{ No adjustments } \\
\hline & $\begin{array}{l}\text { Flexion: }<60^{\circ} \\
\text { Flexion: }>100^{\circ}\end{array}$ & & \\
\hline & Posture /Range & Score & Additional \\
\hline
\end{tabular}




\begin{tabular}{|c|c|c|c|}
\hline \multirow{3}{*}{ 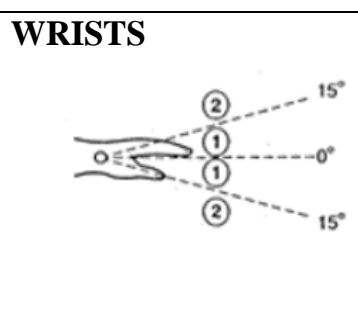 } & $\begin{array}{l}\text { Flexion:0-15 } \\
\text { Extension: } 0-15\end{array}$ & 1 & \multirow{3}{*}{$\begin{array}{l}\text { Wrist } \\
\text { deviated/twisted }\end{array}$} \\
\hline & & & \\
\hline & $\begin{array}{l}\text { Flexion: }>15^{\circ} \\
\text { Extension: }>15^{\circ}\end{array}$ & 2 & \\
\hline
\end{tabular}

Table 4 : Load, Coupling and activity scores.

\begin{tabular}{|l|l|l|}
\hline LOAD/ FORCE & Score & Additional \\
\hline $\begin{array}{l}<5 \mathrm{~kg} \\
<11 \mathrm{lb}\end{array}$ & 0 & \\
\hline $\begin{array}{l}5-10 \mathrm{~kg} \\
11-22 \mathrm{lb}\end{array}$ & 1 & $\begin{array}{l}\text { Shock or rapid } \\
\text { build-up }\end{array}$ \\
\hline $\begin{array}{l}>10 \mathrm{~kg} \\
>22 \mathrm{lb}\end{array}$ & 2 & \\
\hline COUPLING & Score & Left And Right \\
\hline Good & 0 & \multirow{2}{*}{ No adjustments } \\
\cline { 1 - 2 } Fair & 1 & \\
\hline Poor & 2 & Score \\
\hline Unacceptable & 3 & +1 \\
\hline ACTIVITY & & +1 \\
\hline \multicolumn{2}{|l|}{ One or more body parts are static for longer than 1 minute } & +1 \\
\hline Repeat small range motions more than 4 per minute & \\
\hline Rapid large changes in posture or unstable base & \\
\hline
\end{tabular}

Table 5: Table A and Table B scores.

\begin{tabular}{|c|c|c|c|c|c|c|c|}
\hline \multicolumn{3}{|c|}{ TABLE A } & \multicolumn{5}{|c|}{ Trunk } \\
\hline & & & 1 & 2 & 3 & 4 & 5 \\
\hline \multirow{13}{*}{ Neck } & \multirow[t]{6}{*}{1} & Legs & & & & & \\
\hline & & 1 & 1 & 2 & 2 & 3 & 4 \\
\hline & & 2 & 2 & 3 & 4 & 5 & 6 \\
\hline & & 3 & 3 & 4 & 5 & 6 & 7 \\
\hline & & 4 & 4 & 5 & 6 & 7 & 8 \\
\hline & & Legs & & & & & \\
\hline & \multirow{5}{*}{2} & 1 & 1 & 3 & 4 & 5 & 6 \\
\hline & & 2 & 2 & 4 & 5 & 6 & 7 \\
\hline & & 3 & 3 & 5 & 6 & 7 & 8 \\
\hline & & 4 & 4 & 6 & 7 & 8 & 9 \\
\hline & & Legs & & & & & \\
\hline & \multirow[b]{2}{*}{3} & 1 & 1 & 4 & 5 & 6 & 7 \\
\hline & & 2 & 2 & 5 & 6 & -1 & 8 \\
\hline
\end{tabular}

Int. J. Hum. Soc. Dev. Res.

Volume 2, № 2, 2018.66-78 


\begin{tabular}{|c|c|c|c|c|c|c|c|c|}
\hline & & \multicolumn{2}{|l|}{3} & \multirow{2}{*}{$\frac{3}{4}$} & \multirow{2}{*}{\begin{tabular}{|l}
6 \\
7
\end{tabular}} & \multicolumn{2}{|c|}{\begin{tabular}{|l|l|}
7 & 8 \\
\end{tabular}} & \multirow{2}{*}{\begin{tabular}{|l|}
9 \\
9 \\
\end{tabular}} \\
\hline & & 4 & & & & 8 & 9 & \\
\hline \multirow{2}{*}{\multicolumn{3}{|c|}{ TABLE B }} & \multicolumn{6}{|c|}{ Upper Arm } \\
\hline & & & 1 & 2 & 3 & 4 & 5 & 6 \\
\hline \multirow{8}{*}{$\begin{array}{l}\text { Lower } \\
\text { Arm }\end{array}$} & \multirow{4}{*}{1} & Wrist & & & & & & \\
\hline & & 1 & 1 & & 3 & 4 & 6 & 7 \\
\hline & & 2 & 2 & 2 & 4 & 5 & 7 & 8 \\
\hline & & 3 & 2 & 3 & 5 & 5 & 8 & 8 \\
\hline & \multirow{4}{*}{2} & Wrist & & & & & & \\
\hline & & 1 & 1 & 2 & 4 & 5 & 7 & 8 \\
\hline & & 2 & 2 & 3 & 5 & 6 & 8 & 9 \\
\hline & & 3 & 3 & & 5 & 7 & 8 & 9 \\
\hline
\end{tabular}

Table 6: Table $\mathrm{C}$ score for cable pulling process

\section{TABLE C SCORE A}

\begin{tabular}{lllllllllllll|ll} 
& & 1 & 2 & 3 & 4 & 5 & 6 & 7 & 8 & 9 & 10 & 11 & 12 \\
& 1 & 1 & 1 & 1 & 2 & 3 & 3 & 4 & 5 & 6 & 7 & 7 & 7 \\
& 2 & 1 & 2 & 2 & 3 & 4 & 4 & 5 & 6 & 6 & 7 & 7 & 8 \\
& 3 & 2 & 3 & 3 & 3 & 4 & 5 & 6 & 7 & 7 & 8 & 8 & 8 \\
SCORE & 4 & 3 & 4 & 4 & 4 & 5 & 6 & 7 & 8 & 8 & 9 & 9 & 9 \\
B & 5 & 4 & 4 & 5 & 6 & 7 & 8 & 8 & 9 & 9 & 9 & 9 \\
& 6 & 6 & 6 & 6 & 7 & 8 & 8 & 9 & 9 & 10 & 10 & 10 & 10 \\
& 7 & 7 & 7 & 7 & 8 & 9 & 9 & 9 & 10 & 10 & 11 & 11 & 11 \\
& 8 & 8 & 8 & 8 & 9 & 10 & 10 & 10 & 10 & 10 & 11 & 11 & 11 \\
& 9 & 9 & 9 & 9 & 10 & 10 & 10 & 11 & 11 & 11 & 12 & 12 & 12 \\
& 10 & 10 & 10 & 10 & 11 & 11 & 11 & 11 & 12 & 12 & 12 & 12 & 12 \\
& 11 & 11 & 11 & 11 & 11 & 12 & 12 & 12 & 12 & 12 & 12 & 12 & 12 \\
12 & 12 & 12 & 12 & 12 & 12 & 12 & 12 & 12 & 12 & 12 & 12 & 12
\end{tabular}




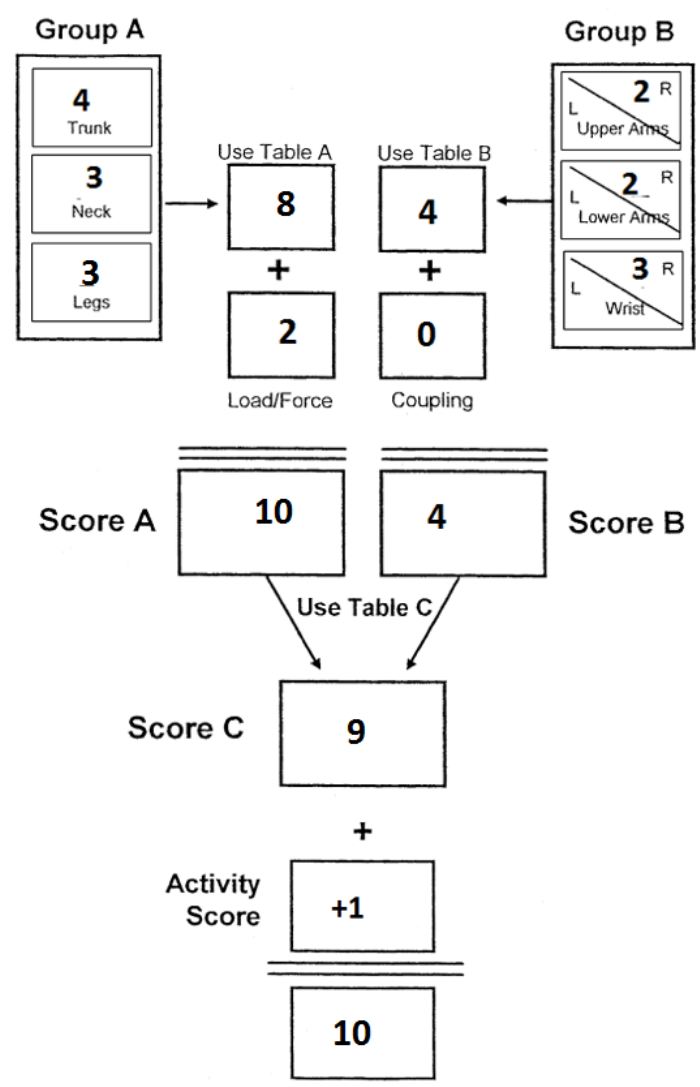

Figure 4: REBA Final Score

Table 7: REBA Precautions Levels

$\begin{array}{llll}\begin{array}{l}\text { Action } \\ \text { level }\end{array} & \begin{array}{l}\text { REBA } \\ \text { score }\end{array} & \text { Risk level } & \begin{array}{l}\text { Action } \\ \text { (Including further assessment) }\end{array} \\ 0 & 1 & \text { Negligible } & \text { None necessary } \\ 1 & 2-3 & \text { Low } & \text { May be necessary } \\ 2 & 4-7 & \text { Medium } & \text { Necessary } \\ 3 & 8-10 & \text { High } & \text { Necessary soon } \\ 4 & 11-15 & \text { Very high } & \text { Necessary now }\end{array}$




\section{Discussion}

MSDs are a costly and prevalent problem for employees and companies all around the world. MSDs have big ratio in the workplace injuries and absenteeism. MSDs affect the human body's movement or musculoskeletal system such as tendons, ligaments, nerves, discs, muscles etc. After examination of healthy records, it is seen that manually cable pulling works cause MSDs. Employees start to fatigue and develop a musculoskeletal imbalance. Finally, fatigue causes musculoskeletal disorder develops cause of repeat tasks by the time. Therefore, manually cable pulling process are analyzed using REBA ergonomic risk assessment method.

The REBA is a tool that scores the tasks for biomechanical risk factors and where employees might be exposed (19-20). According to total REBA score, REBA action level of 3 is obtained indicating a high risk of injury to the manually cable pulling process employees. This REBA score corresponds to necessary soon. Therefore, some precautions are taken immediately.

\footnotetext{
$\checkmark \quad$ Training about true postures provided to employees.

$\checkmark \quad$ Electric/hydraulic cable pulling equipment's supplied.

$\checkmark \quad$ Increased number of portable pulleys.

$\checkmark \quad$ Done rotation and shorten working periods.

$\checkmark \quad$ Increased rest break times.
}

Healthy records that is about only cable pulling employees in 6 months after improvements are shown table 8 . Due to this data it is clearly seen decreasing on employees who have healthy problems. After improvements, total number of employees who have healthy records are 16. (\% 64,38 decreasing) 18 and 25 ages employees have 2 mild low-back pain and 3 soft tissue injury. At this ages \% 64,28 decrease is seen. 26 and 35 ages employees have 2 mild low-back pain and 2 soft tissue injury. At this ages \% 85,18 decrease is seen. Over 35 age's employees have 3 mild low-back pain, 1 severe low back pain, 1 mild low hand and leg pain, 1 severe low hand and leg pain and 1 soft tissue injury. At this ages \% 78,12 decrease is seen. Also days of temporary incapacity is 47 . Lost working days at the cable pulling works decreased \%89,5. 
Table 8: Healthy records that is about only cable pulling employee's in 6 months after improvements.

$\begin{array}{llllll}\text { Ailments } & \begin{array}{l}\text { Number of } \\ \text { employees }\end{array} & \begin{array}{l}18-25 \text { ages } \\ \text { employees }\end{array} & \begin{array}{l}26-35 \text { ages } \\ \text { employees }\end{array} & \begin{array}{l}\text { Over } \\ \text { ages } \\ \text { employees }\end{array} & \begin{array}{l}\text { Days of } \\ \text { temporary } \\ \text { incapacity }\end{array} \\ \begin{array}{l}\text { mild low- } \\ \text { back pain }\end{array} & 7 & 2 & 2 & 3 & 14 \\ \begin{array}{l}\text { severe low- } \\ \text { back pain }\end{array} & 1 & - & - & 1 & 5 \\ \begin{array}{l}\text { Mild low } \\ \text { hand and leg } \\ \text { pain }\end{array} & 1 & - & - & 1 & 3 \\ \begin{array}{l}\text { Severe low } \\ \text { hand and leg } \\ \text { pain }\end{array} & 1 & - & - & 1 & 2 \\ \begin{array}{l}\text { soft tissue } \\ \text { injury }\end{array} & 6 & 3 & 2 & 1 & 23 \\ \text { Total } & 16 & 5 & 4 & 7 & 47 \text { lost day }\end{array}$

In conclusion we have taken healthy records and analyzed process with using REBA. Due to high risk level, we applied some precautions. After taken precautions, it is find out high level progress.

\section{Disclosure statement}

No potential conflict of interest was reported by the authors.

\section{Contact Information}

E-mail: hakann@gmail.com 


\section{References and notes:}

Kirkhorn SR, Earle-Richardson G, Banks RJ.(2010) Ergonomic risks and musculoskeletal disorders in production agriculture: Recommendations for effective research to practice. J Agromedicine. 2010; 15:pp.281-99.

Levy B, Wegman D. (2000). Occupational health: recognizing and preventing workrelated disease and injury. Lippincott Williams \& Wilkins.

Bureau of Labor Statistics. Musculoskeletal disorders and days away from work in 2007. The Economics Daily. 2008. Available from: http://www.bls.gov/opub/ted/2008/dec/wk1/art02.htm

Marras WS.(2000) Occupational low back disorder causation and control. Ergonomics. 43:pp.880-902.

Das T, Gangopadhyay S. (2005) A critical evaluation of the probable causes of musculoskeletal disorders prevalent among the manual material handling workers of a construction industry. Proceedings of International Ergonomics Conference (HWWE 2005); p. 128.

OSHA (Occupational Safety \& Health Administration) (2017) https://www.osha.gov/SLTC/ergonomics/ Accessed November 23, 2017.

CCOHS (Canadian Centre for Occupational Health and Safety) (2009) https://www.labour.gov.on.ca/english/hs/pubs/pains/ Accessed November 23, 2017.

Mathiassen S, Liv P, Wahlström J. (2012)Cost-efficient observation of working postures from video recordings - more videos, more observers or more views per observer? Work. 41(Supl 1):2302-6. PMid: 22317059. http://dx.doi. org/10.3233/WOR-2012-0456-2302.

Motamedzade M, Ashuri MR, Golmohammadi R, Mahjub H.(2011). Comparison of ergonomic risk assessment outputs from rapid entire body assessment and quick exposure check in an engine oil company. J Res Health Sci. 11(1):pp.26- 32. PMid: 22911944.

Kim S, Nussbaum MA, Jia B. (2011).Low back injury risks during construction with prefabricated (panelised) walls: effects of task and design factors. Ergonomics. 54:60-71. PMid: 21181589. http://dx.doi.org/10.1080/00140139.2 010.535024.

Gentzler M, Stader S.(2010) Posture stress on firefighters and emergency medical technicians (EMTs) associated with repetitive reaching, bending, lifting, and pulling tasks. Work.37(3):227-239. PMid: 20978330. http://dx.doi. org/10.3233/WOR-2010-1075.

Mokkink L, Terwee C, Patrick D, Alonso J, Stratford P, Knol D, et al.(2010) The COSMIN checklist for assessing the methodological quality of studies on measurement properties of health status measurement instruments: an international. Qual Life Res. 19: 539-49. PMid: 20169472 PMCid: PMC2852520. http://dx.doi.org/10.1007/s11136-010-9606-8.

Beaton DE, Bombardier C, Guillemin F, Ferraz MB. (2000).Guidelines for the process of cross-cultural adaptation of self-report measures. Spine (Phila $\mathrm{Pa} 1976$ ). 25(24):3186-91. http://dx.doi. org/10.1097/00007632-200012150-00014.

McAtamney, L. and N.E. Corlett, 1993. RULA: A survey method for the investigation of work-related upper limb disorders. Applied Ergonom. , 24:pp. 91-99. DOI: 10.1016/0003-6870(93)90080-S. 
David, G., 2005. Ergonomic methods for assessing exposure to risk factors for workrelated musculoskeletal disorders. Occupat. Med., 55:pp. 190-199. DOI: 10.1093/occmed/kqi082

Chiasson, M., D. Imbeau, K. Aubry and A. Delisle, 2012. Comparing the results of eight methods used to evaluate risk factors associated with musculoskeletal disorders. Int. J. Indust. Ergonom., 42: 478-488. DOI: 10.1016/j.ergon.2012.07.003.

Shanahan, C., P. Vi, E. Salas, V. Reider and L. Hochman et al., 2013. A comparison of RULA, REBA and Strain Index to four psychophysical scales in the assessment of non-fixed work. Work, 45: 367-378. DOI: 10.3233/WOR121540.

Coyle, A., 2005. Comparison of the rapid entire body assessment and the New Zealand manual handling 'hazard control record', for assessment of manual handling hazards in the supermarket industry. Work, 24: 111-116.

McAtamney L, Hignett S. (1995).REBA: a rapid entire body assessment method for investigating work related musculoskeletal disorders; Annual Conference Ergonomics Society of Australia 31st Annual Conference Ergonomics Society of Australia; Annual Conference Ergonomics Society of Australia 31st Annual Conference Ergonomics Society of Australia; 13-15 Dec 1995; Glenelg. Glenelg: Ergonomics Society of Australia; pp. 45-51.

Hignett S, McAtamney L. (2000) Rapid entire body assessment (REBA) Appl Ergon.31:201-205. http://dx.doi.org/10.1016/S0003-6870(99)00039-3 [PubMed] 